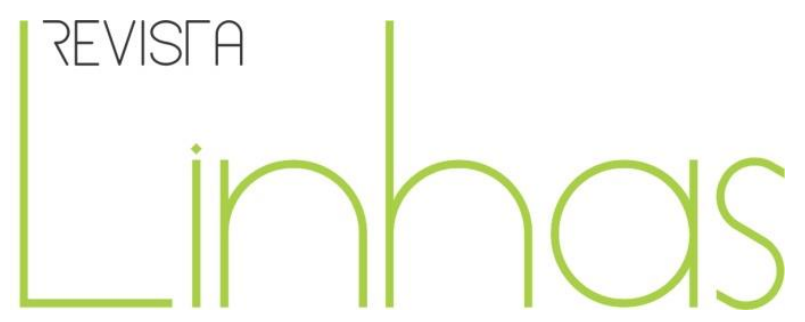

\title{
Flores tristes: la represión franquista en Galicia a través del cine documental
}

\begin{abstract}
Resumen
La persecución política puede darse en un contexto de violencia producida por el conflicto armado entre países, o como terrorismo de estado en el ejercicio del poder, entre otras formas. La persecución política llevada a cabo en España por el régimen de Franco a partir del golpe de estado, el 18 de julio de 1936, significó la ruptura violenta de la legalidad constitucional y abrió, a partir de ese momento, un proceso de muertes, condenas, castigos administrativos y exilios que abarcó a toda la sociedad española. Por otro lado, el cine documental tiene un extraordinario interés didáctico que lo convierte en un atractivo recurso para su empleo en las aulas. En el caso de la Historia de la educación, ofrece enormes posibilidades para el estudio y comprensión de la memoria histórica relacionada con la represión en cualquiera de sus formas. El presente trabajo analiza el documental Flores tristes (Teo Manuel Abad, 2008) como un recurso interesante para explicar el proceso de represión política en Galicia (España) a partir del golpe de estado. Al mismo tiempo, se pone en relación con otros procesos de represión política en el contexto latinoamericano, para lo que se sugieren algunos ejemplos de cine documental que pueden utilizarse en dichos contextos. Para ello se ha revisado diversa bibliografía relacionada con el cine y el género documental; con la represión franquista en España y Galicia; y se ha analizado diverso material audiovisual de acceso online cuya relación aparece citada en el texto.
\end{abstract}

Palabras clave: Cine documental. Represión política. Franquismo. Historia de la educación.
Xosé Manuel Malheiro Gutiérrez

Universidade A Coruña - Espanha

jose.malheirog@udc.es

\section{Para citar este artigo:}

GUTIÉRREZ, Xosé Manuel Malheiro. Flores tristes: la represión franquista en Galicia a través del cine documental. Revista Linhas. Florianópolis, v. 21, n. 47, p. 10-44, set./dez. 2020. 


\section{Flores tristes: Franco's repression in Galicia through documentary film}

\begin{abstract}
Political persecution can occur in a context of violence produced by armed conflict between countries, or as state terrorism in the exercise of power, among other forms. The political persecution carried out in Spain by the Franco regime since the coup d'état on July 18,1936 , meant the violent rupture of constitutional legality and opened, from that moment on, a process of deaths, convictions, administrative punishments and exile that encompassed all of Spanish society. Documentary film has an extraordinary didactic interest that makes it an interesting resource for use in the classroom. In the case of the History of Education, it offers enormous possibilities, among other topics, for the study and understanding of historical memory related to repression in any of its forms. This work analyses the documentary Flores tristes (Teo Manuel Abad, 2008) as an interesting resource to explain the process of political repression in Galicia (Spain) after the coup d'état. At the same time, it relates to other processes of political repression in the Latin American context, suggesting some examples of documentary filmmaking that can be used as a resource in such contexts. To this end, various bibliographies related to cinema and the documentary genre have been reviewed, as well as to the repression of Franco in Spain and Galicia.
\end{abstract}

Keywords: Documentary filmmaking. Political represión. Francoism. History of education.

\section{Flores tristes: a repressão do regime franquista na Galiza a través do cinema documental}

\section{Resumo}

A perseguição política pode ocorrer num contexto de violência produzida por conflitos armados entre países, ou como terrorismo de Estado no exercício do poder, entre outras formas. A perseguição política levada a cabo em Espanha pelo regime de Franco desde o golpe de Estado de 18 de Julho de 1936, significou a violenta quebra da legalidade constitucional e abriu, a partir desse momento, um processo de mortes, condenações, punições administrativas e exílio que cobriu toda a sociedade espanhola. Por outro lado, o filme documentário tem um extraordinário interesse didáctico que o torna um recurso atractivo para utilização na sala de aula. No caso da História da Educação, oferece enormes possibilidades para $\mathrm{o}$ estudo e compreensão da memória histórica relacionada com a repressão em qualquer das suas formas. Este trabalho analisa o documentário Flores tristes (Teo Manuel Abad, 2008) como um recurso interessante para explicar o processo de repressão política na Galiza (Espanha) após o golpe de estado. Ao mesmo tempo, relaciona-se com outros processos de repressão política no contexto latino-americano, sugerindo alguns exemplos de realização de filmes documentários que podem ser utilizados em tais contextos. Para o efeito, foi revisada diversa bibliografia relacionada com o cinema e o género documental, bem como com a repressão de Franco em Espanha e na Galiza. Foram também analisados vários materiais audiovisuais de acceso online, cuja relação aparece citada no texto.

Palavras-chave: Documentário. Repressão política. Regime de Franco. História da educação. 
Un país sin cine documental es como una familia sin álbum de fotografías

Patricio Guzmán

Tradicionalmente, la documentación escrita y mayoritariamente en soporte papel ha sido la opción más manejada por los historiadores e historiadoras para investigar o para explicar, enseñar o difundir el resultado de sus investigaciones. El panorama fue cambiando, y desde hace unas décadas, los textos escritos ya no son más que una de las variadas fuentes, o más recientemente, 'vestigios'. Entre los citados por Peter Burke, que toma la expresión del historiador Gustaaf Renier (1892-1962), figuran los manuscritos, los libros impresos, los edificios, el mobiliario, el paisaje y diversos tipos de imágenes (pinturas, estatuas, grabados, fotografías... ) para acercarnos al pasado y tratar de interpretarlo con el fin de comprender mejor la realidad presente $(2005,16)$. Unido a esto, en las últimas décadas, los historiadores han ampliado considerablemente sus campos de investigación hasta incluir no sólo los acontecimientos políticos, las tendencias económicas o las estructuras sociales, sino también la historia de las mentalidades, de la vida cotidiana, de la cultura material, etc. Pero no habrían podido llevar a cabo sus investigaciones sobre estos campos relativamente novedosos, sin el apoyo de estas nuevas fuentes, además de las tradicionales, entre las que se encuentran la fotografía y el cine. Porque tanto la fotografía, como su prolongación, el cine, inauguran un fenómeno sin precedentes que supone que, en su ámbito, los materiales fundamentales a través de los que se trabaja proceden directamente de la realidad (CATALÁ y CERDÁN, 2008).

Remontándose a sus orígenes, Erik Barnouw (2005) defiende en una obra ya clásica, que el cine no nace para crear ficción, sino "por la necesidad imperiosa de documentar algún fenómeno o acción". Y en este sentido, los diez primeros cortos de apenas 50 segundos con los que se inaugura la era del cine (entre ellos, la célebre Salida de la fábrica, presuntamente rodada el 19 de marzo de 1895), que componen la primera exhibición pública del cinematógrafo Lumière, el 28 de diciembre de 1895 en el Salon Indien del Grand Café de París, ya condensan la esencia del estilo cinematográfico documental. ${ }^{1}$ Un género,

\footnotetext{
${ }^{1}$ El documental Lumière! L'aventure commence (2016) recoge una selección de 108 de aquellos cortos que fueron objeto de exhibición pública desde 1895 a 1905, recuperados digitalmente por iniciativa de Thierry Fremaux director artístico del Instituto Lumière con el apoyo de Bertrand Tavernier y de Martin Scorsese.
} 
justamente denominado de lo real, que habitualmente emplea materiales extraídos del ámbito histórico, pudiendo afirmarse que trabaja el mundo hecho imagen. Pero a diferencia del cine de ficción, el género documental "no puede ser una reconstrucción, debe ser 'verdad', con personas y situaciones reales"' (BARSAM,1973, p. 15). A esta premisa ontológica se le añade además un sentido ético, pues intenta preservar el rasgo de veracidad como característica propia, ante la deriva hacia la ficción o lo estético que experimentan el cine y la fotografía (CATALÁ y CERDÁN, 2008, p. 8).

Por todo esto, el cine documental tiene un extraordinario interés didáctico en las distintas ramas de la historia, que lo convierte en un recurso interesante y cada vez más empleado en las aulas (BREU, 2010). A ello hay que sumar su paulatina accesibilidad gracias a la popularización de los soportes digitales y a las posibilidades que ofrece la Red. En el caso de la Historia de la educación, el cine documental presenta innumerables recursos, entre otros temas, para el estudio y comprensión de la memoria histórica relacionada con la represión en cualquiera de sus formas.

\section{El género documental como denuncia social de la represión política}

La represión, como la define Antonia del Rey, es la persecución violenta del enemigo político, de aquél que defiende otra ideología, otros valores, otros símbolos. En ocasiones va unida a fenómenos violentos de mayor envergadura, como son las guerras y las revoluciones; en otras es una práctica del poder, sobre todo, en los regímenes totalitarios. “En el primer caso, la represión es anárquica, sin garantías legales, muy poco sutil y muchas veces motivada por el miedo del propio represor ante la represión del enemigo. En el segundo caso, la represión es sistemática, con aparentes garantías legales, posee infinidad de procedimientos y es producto del maniqueísmo de quien se cree defensor del bien" (1998, p. 56).

Documentar la represión en forma de crímenes de guerra fue objeto de atención por parte de los diferentes gobiernos en conflicto a lo largo del siglo XX. Barnouw (2005, pp. 155-164) cita como ejemplos las atrocidades de los nazis en Croacia denunciadas por los

Puede verse el tráiler en el siguiente enlace: https://www.youtube.com/watch?v=BO6wX6lzmp8. 
partisanos yugoslavos (Jasenovac, 1945) ${ }^{2}$ o los sucesos paralelos ocurridos en campo de concentración de Majdanek, en la Polonia ocupada (Majdanek, 1944). ${ }^{3}$ Las tomas de los crímenes de guerra, acompañadas de otra documentación, fueron claves también para que los fiscales pudieron construir en Nuremberg su caso contra los nazis, presentando como pruebas sus propias películas y registros. En este caso, los juicios se filmaron íntegramente y este material combinado llegó a ser la base de dos largometrajes documentales: el soviético Sud Naradov (El juicio de las naciones, 1946) ${ }^{4}$ dirigido por Roman Karmen, y el norteamericano Nürnberg (Nuremberg, 1948). ${ }^{5}$

En otras ocasiones, el documental se convierte en un instrumento de propaganda antagonista entre estados enfrentados o en conflicto bélico. Un ejemplo interesante es el realizado por el alemán oriental Joachim Hellwing. En Ein Tagebuch für Anne Frank (Un diario para Ana Frank, 1958), ${ }^{6}$ Hellwing utiliza material de archivo para seguir el rastro de aquéllos que habían aprobado el arresto, deportación y muerte de la niña alemana y los localiza ocupando posiciones influyentes en la Alemania Occidental, lo que sirvió como elemento de presión para emprender acciones legales contra los criminales de guerra.

Desde sus inicios, el cine documental se ha desarrollado ligado al interés social. Desde la propaganda de guerra o la aportación de documentación judicial, como acabamos de ver, hasta la información periodística, la reconstrucción historia, la crítica política, el análisis económico, la educación social, la concienciación ecológica o la denuncia ambiental. En todas sus vertientes, persiste el objetivo de llevar al espectador hacia el campo de la reflexión.

\footnotetext{
${ }^{2}$ Acceso a documental: https://www.youtube.com/watch?v=CSoy3NWZspE.

${ }^{3}$ Acceso a documental: https://www.youtube.com/watch?v=u7cbd6w3nLQ.

${ }^{4}$ Acceso a documental: https://www.youtube.com/watch?v=UCdnHG7r1lo\&bpctr=1588246899.

${ }^{5}$ Acceso a documental: https://www.youtube.com/watch?v=rdN3p739hOg.

${ }^{6}$ Acceso a documental: https://www.youtube.com/watch?v=At8gl8Q1QRo.
} 


\section{Flores tristes (Galicia, España, 2008)7: entre la denuncia y la dignificación}

La represión que siguió a la rebelión militar y continuó durante la guerra y el primer franquismo, encuentran en el género documental un excelente recurso para acompañar la revisión bibliográfica y las sesiones magistrales, entre otro conjunto de posibilidades como parte de las tareas académicas. En este sentido, Flores tristes es un valioso material de trabajo para el estudio de la represión franquista en Galicia después del golpe de estado perpetrado el 18 de julio de 1936.

Flores tristes es el resultado de una minuciosa labor de investigación que da voz a los represaliados y represaliadas del franquismo través del testimonio de sus familiares. Este trabajo parte de la propia experiencia de Teo Manuel $\mathrm{Abad}^{8}$ en conversaciones familiares, al conocer cómo se vivía el terror de las noches y la presencia de cadáveres en las cunetas, al salir de casa por las mañanas. Y es, a la vez, un reconocimiento moral a los represaliados, muchos de ellos todavía desaparecidos. ${ }^{9}$

\footnotetext{
7 Teo Manuel Abad (Director); Teo Manuel Abad, Carmen Carballo (Guión); Formateo / Pórtico de Comunicaciones S.L / Televisión de Galicia (TVG) S.A / Tic Tac (Producción); José Luis Caamaño, Diego Frey (Fotografía); Manuel Conde (Música); duración: 120.

${ }^{8}$ Teo Manuel Abad es un realizador de amplia trayectoria en el audiovisual gallego, cuyos comienzos están en la fotografía como corresponsal gráfico en diversos medios. A mediados de los 80 se inicia en el mundo de la video-creación, y entra a formar parte del primer equipo técnico de la Televisión de Galicia, donde desarrolla una notable labor innovadora como realizador en numerosos programas. (http://www.florestristes.com/pelicula03.html). Flores tristes mereció el premio al largometraje documental en la VII Edición de los premios Mestre Mateo de la Academia Galega do Audiovisual, 2008.

9 Para ahondar en el tema de la represión franquista en Galicia debe consultarse el proyecto interuniversitario de investigación Nomes e Voces (http://www.nomesevoces.net/gl/presentacion/). Dicho proyecto tiene por objeto el estudio permanente de la represión durante la Guerra Civil y la dictadura, así como ofrecer a la sociedad los datos relativos a las personas que sufrieron algún tipo de persecución a causa de su ideología o de su posición favorable a la democracia republicana. Tarea que se aborda desde la perspectiva de la investigación histórica, como parte de un creciente interés de los especialistas por el tema de la Guerra Civil y de la consiguiente represión.
} 


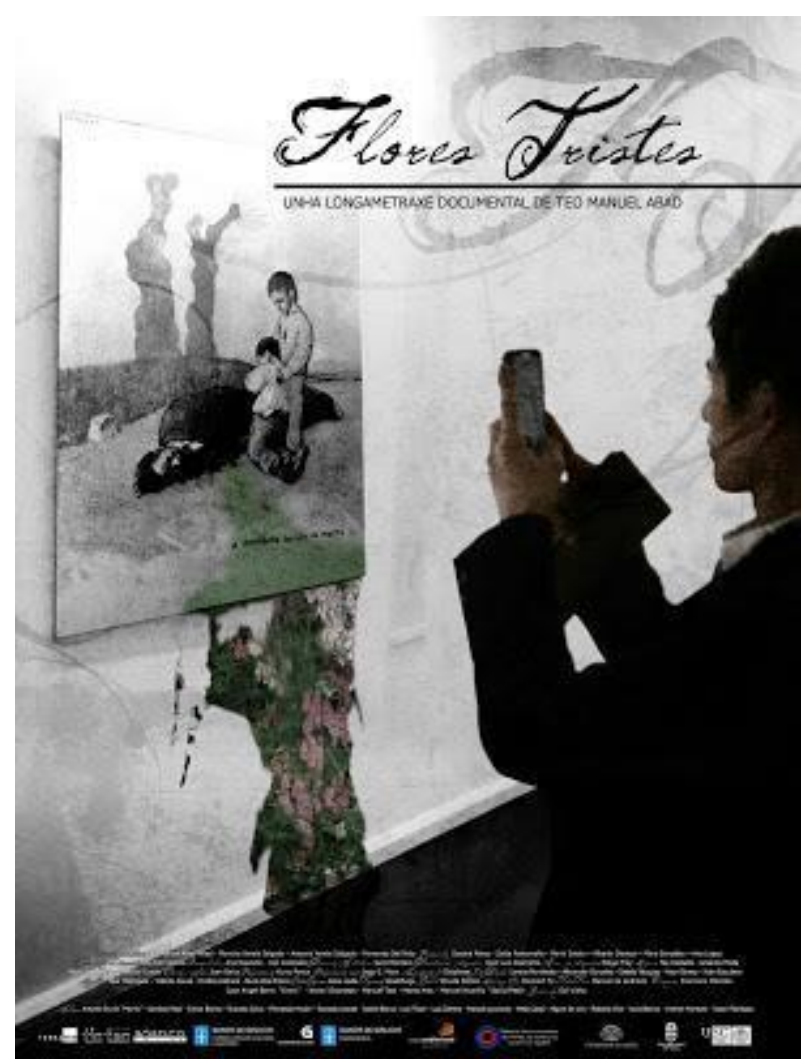

Ilustración $n^{\circ}$ 1. Flores tristes (2008), un retrato minucioso y completo de la represión franquista en Galicia.

Teo Manuel Abad traslada los testimonios a los lugares físicos donde ocurrieron los hechos, que combina con imágenes impactantes de las exhumaciones realizadas en fosas comunes, con recreaciones dramatizadas de "paseos"10 y fusilamientos, además de ilustraciones de la colección Atila en Galiza y Galiza Mártir, de Castelao ${ }^{11}$ e imágenes y fotografías de archivo.

\footnotetext{
${ }^{10}$ Paseo fue un eufemismo muy utilizado durante la guerra para referirse a la localización de las víctimas en sus domicilios, con posterior secuestro, con la excusa de sacarles a dar un paseo, que solía acabar en asesinato en algún monte o camino apartado, luego de su traslado hasta allí, generalmente de noche.

${ }^{11}$ Alfonso Daniel Rodríguez Castelao es un referente político y moral del nacionalismo gallego, además de intelectual y artista, que en su amplia obra literaria y pictórica reflejó un hondo compromiso con Galicia. Fue Presidente del Consello de Galiza, una especie de gobierno en el exilio argentino, hasta su muerte en 1950. Sus restos, traídos a Galicia en 1984, descansan en el Pabellón de Gallegos llustres, en Santiago de Compostela, junto a los poetas Rosalía de Castro y Ramón Cabanillas, el político regionalista Alfredo Brañas, el escultor Francisco Asorey y el geógrafo Domingo Fontán. En 1964, la Real Academia Gallega le dedicó el Día das Letras Galegas. Más información en el perfil: https:/academia.gal/figuras-homenaxeadas//journal_content/56_INSTANCE_8kIA/10157/28701. Consultado 19/04/2018. Por otro lado, Galiza Mártir y Atila en Galiza (1937) forman junto con Milicianos (1938) los Álbumes de Guerra, un conjunto de estampas que Castelao realizó para denunciar las barbaridades de la represión durante la Guerra Civil española. Puede
} 
Señala que las últimas fosas comunes abiertas en Europa no fueron en Srebrenica o en Kosovo, donde tuvo lugar la más reciente guerra civil europea, sino en Galicia, ${ }^{12}$ en el extremo más occidental del continente. Han tenido que pasar 70 años para que se iniciaran las primeras excavaciones. A partir de este hecho, se teje un denso relato en el que intervienen familiares (algunos más conocidos como Isaac Díaz Pardo, hijo de Camilo Díaz Baliño; Xosé Luis Bóveda, hijo de Alexandre Bóveda, Esther Varela, nieta de Santiago Casares Quiroga) de aquellos que fueron asesinados y enterrados en las cunetas y fosas comunes y que todavía permanecen diseminados "por el mapa torturado de Galicia". Cuenta también con las aportaciones de historiadores e investigadores como Emilio Grandío, Carmen Blanco, Claudio Rodríguez Fer, Ángel Rodríguez Gallardo, Enrique Barrera o Dionisio Pereira, que ayudan a ilustrar los distintos aspectos de la represión. Interviene, además, un grupo de actores y actrices que ponen voz a diversos textos literarios o a documentos históricos, que el documental coloca en diferentes escenarios, cargados de un fuerte simbolismo para resaltar algunas escenas de la represión.

(15’06”) Aquel verano del 36 fue muy caluroso. Los cadáveres se descomponían muy rápidamente al sol y se derretían contra el suelo. La tierra, sorprendida, enseguida quedó preñada de la sangre que buscaba con prisa nueva vida, y de esta mezcla surgió la resurrección. Surgieron flores, flores hermosas, humildes, tiernas, sorprendidas y espantadas. Flores que huyeron de las botas militares. Flores que sobrevivían aferrándose al miserable e inevitable hábitat que tenían por destino. Quedaron flores, quedaron hijos, hermanos, sobrinos, primos... quedó, sin tenerlo previsto, la vida que inconscientemente sembraron los asesinos. Así, hinojos, malvas, cardos, las humildes hierbas de los caminos y senderos de Galicia nos enseñaron toda esta generación que nació de la sangre de un pueblo humillado.

accederse al conjunto de la obra: https://albumesdeguerra.pressbooks.com/front-matter/significadoalbumes-de-guerra-castelao/

${ }^{12}$ Situada en el noroeste peninsular e integrada en el Estado español, Galicia se define en su historia por una alta densidad sociológica rural y marinera. Posee unas marcadas señas de identidad al conformar una unidad geográfica, histórica, cultural y lingüística que le da carácter de nacionalidad. Junto con el País Vasco y Cataluña forman las denominadas Comunidades Autónomas históricas dentro de la organización política actual del territorio español. Véase: Xusto G. Beramendi (2016). Historia mínima de Galicia. Madrid, Turnes Ediciones. 
El título evoca, a modo de metáfora, la tristeza de las flores que nacen a la orilla de los caminos y crecen nutridas por la sangre de miles de víctimas, asesinadas (02'20”) “por bandas de criminales que arrasaron los campos, las familias, los pueblos y las ciudades, sembrando regueros de sangre" después del golpe de estado, comandado por el general Franco, el 18 de julio de 1936.

\section{Los paseos como medida de coacción y prevención}

Mientras el actor Luis Tosar camina por un bosque, testigo quizá de alguna persecución criminal en otro tiempo, recita los párrafos de un texto inserto en la causa 1343/36 ATMT No IV referida al escritor Antonio Ramos Varela:13

(7'40") Y a la luz de las estrellas han salido en marcial formación y se han apoderado de todo. A la mañana siguiente empezó la matanza. A los primeros los mataron solo para probar las armas, porque hacía mucho tiempo que no las usaban. Mientras, yo estaba en el bosque y me ocultaba de todo hombre, porque toda figura de hombre era la imagen del asesinato. Nunca el mundo fue tan poco real como en esos días. ${ }^{14}$

Aquel golpe de estado significó la ruptura violenta del régimen político constitucional y abrió, a partir de ese momento, durante toda la etapa de rebelión armada, y especial crudeza durante las primeras décadas de la dictadura un período de represión con resultado de miles de muertos por secuestro, torturas y asesinato... Como señala Virginia Guichot,

hay que incluir, tras la Guerra Civil, alrededor de cuatrocientos mil individuos que pasaron por campos de concentración y centenares de miles de presos. Y no es baladí recordar que las últimas ejecuciones del franquismo se produjeron el 27 de septiembre de 1975, menos de un mes

\footnotetext{
13 Antonio Ramos Varela fue declarado "de afiliación anarco sindicalista y sujeto peligroso, gran propagandista de sus ideales y de mucha ascendencia por su vasta cultura" figurando en las listas de "indeseables huidos". Fue juzgado en Compostela por rebelión militar en 1936 y condenado a pena de muerte, conmutada por cadena perpetua y posteriormente conmutada por seis años de prisión menor. Quedó en libertad provisional en 1943 y murió de tuberculosis dos años después. Véase: Otero Urtaza, (2008).

${ }^{14} \mathrm{~A}$ volta dos nove (Antón Caeiro, 2015) reconstruye una violenta venganza que acabó con el asesinato a sangre fría de nueve marineros de Nigrán y Baiona (Pontevedra), después de que dos de ellos mataran por accidente a un falangista.
} 
antes de la muerte de Franco, en las que murieron por fusilamiento cinco hombres, tres miembros del Frente Revolucionario Antifascista y Patriota (FRAP) y dos de Euskadi Ta Askatasuna (ETA). No, desde luego, el panorama no parecía muy alentador para un tránsito exitoso hacia un régimen democrático (2017, p. 72$).^{15}$

En el cementerio compostelano de Boisaca, Luis Zahera refiere un fragmento de la causa 937/36, del Archivo del Tribunal Militar Territorial IV (A Coruña) que ilustra este hecho:

(19'06") Con referencia al señalado como Otero, Camarero del Méndez Núñez, se tiene noticia de que es uno de los que en estos últimos días apareció muerto por violencia, ignorándose las causas de ellos...; El Chaquetilla, parece ser se trata de un tal Jesús Barcia Arias,... sujeto que también ha aparecido estos días muerto por violencia; el Cesáreo de la Flota Pesquera, es otro elemento destacadísimo en el aspecto social... también ha aparecido muerto por violencia; Pedro Galán Calvete... es otro de los sujetos que ha aparecido muerto por violencia días pasados; el camarero del Café New York, se trata, por las señas, de José Avelino Méndez... hay noticias de que este sujeto apareció muerto por violencia, pero este extremo no ha sido comprobado; el señalado como NITO, por las señas se trata de Juan Otero Canosa, que vivía en Vilaboa, sujeto que fue fusilado en las proximidades de Zamora por Fuerzas de Ejército;... Ramón Ponte Rivas,... elemento destacado por sus ideas extremistas, y sujeto que apareció muerto por violencia en días anteriores; Pedro, de oficio panadero, parece ser un panadero que también apareció muerto por violencia y que se llamaba Pedro Teijo".

A los miles de asesinatos de personas inocentes (muchos de ellos todavía siguen desaparecidos, enterrados en fosas comunes y sin identificar) deben sumarse encarcelamientos, castigos administrativos en la zona ocupada y exilios que afectaron de forma dramática a los diferentes colectivos sociales, culturales e intelectuales de Galicia afectos a la República:

(08'08") En el pequeño país, el ejército y las fuerzas policiales se hicieron con los principales centros de decisión y anularon el funcionamiento de las instituciones democráticas. Con extrema violencia fueron aplastando los

\footnotetext{
${ }^{15}$ Las últimas ejecuciones ordenadas por Franco fueron el 27 de septiembre de 1975, en relación con cuatro causas instruidas por la jurisdicción militar por delitos de terrorismo y de agresión a fuerza armada, fueron las de José Humberto Francisco Baena Alonso, Ramón García Sanz, José Luis Sánchez-Bravo Solla, Ángel Otaegui Echevarría y Juan Paredes Manot.
} 
pequeños actos de resistencia que, en defensa de la legalidad, se fueron produciendo por todo el territorio. A partir de aquí, comienza la lenta sangría de muertos: los muertos oficiales y los muertos clandestinos o desaparecidos.

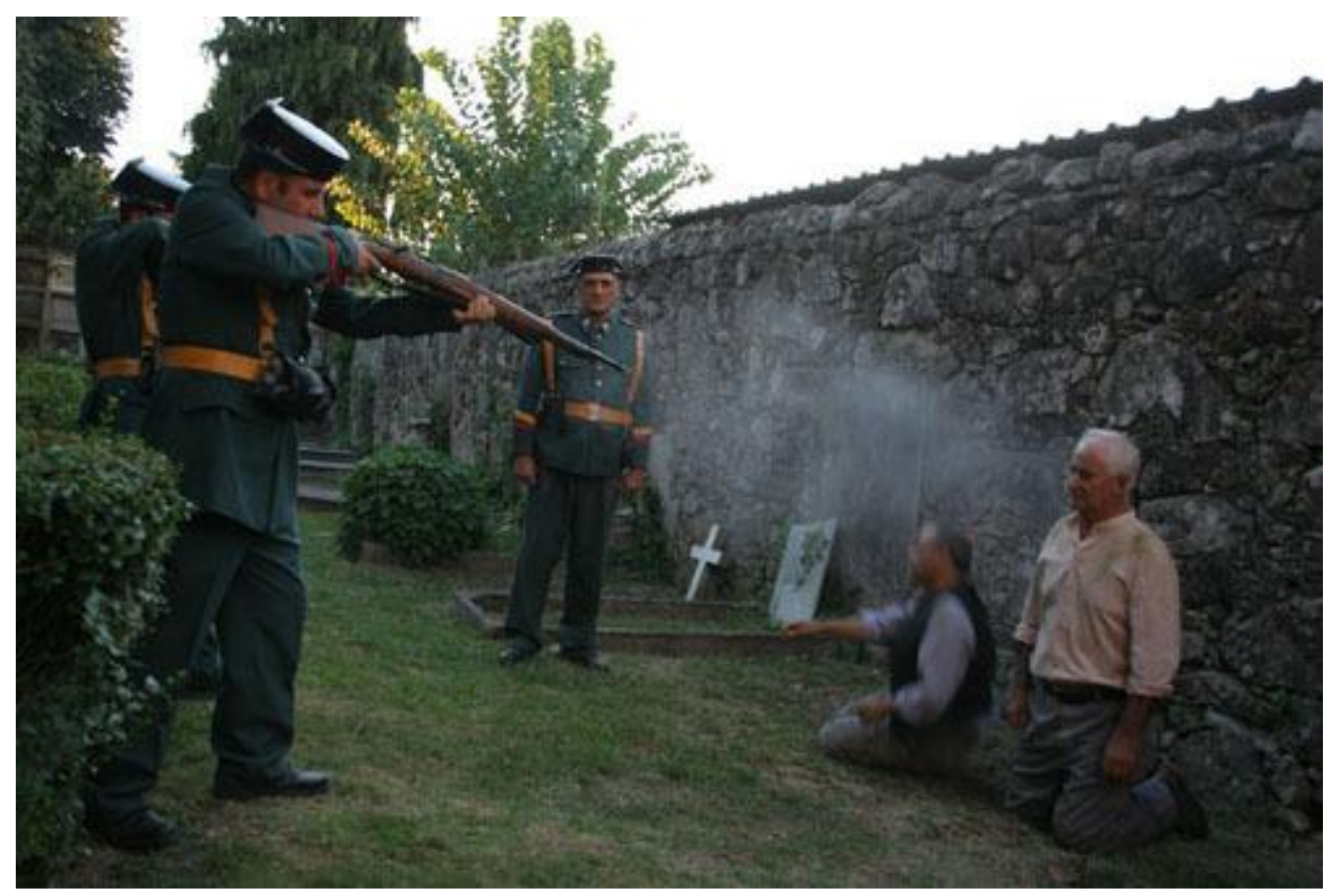

Ilustración $n^{\circ}$ 2. José Antonio Primo de Rivera: “"Hay veces en la vida en que se acaban los razonamientos y sólo queda la dialéctica de los puños y las pistolas".

Otra secuencia del documental nos sitúa en el recinto ensangrentado de un matadero industrial donde el actor Evaristo Calvo describe la barbarie de las torturas a través de un fragmento de la novela Home sen nome, del escritor Suso de Toro:

(46’05”) Sí, nosotros conocimos este mes pasado la libertad total. La libertad sin límites, nunca se había visto antes. Nunca se verá. El mundo al revés. Gente de la canalla, los amos de las tabernas golpeando a las autoridades de la ciudad. Matándolas como a perros. Si, como a perros, no como a gente. Fue un mes de libertad y juerga. Con certeza que bebimos vino y aguardiente, licor café por la noche en las tabernas. Decidimos 'pasear' gente. Nuestras ciudades fueron una fiesta para los camaradas, e hicimos lo que queríamos. Fuimos a buscar a la gente a sus casas y los 
matamos como conejos. No faltó la carne este mes, hubo carne fresca. ¿Alguna vez matasteis un conejito, chavales? ¿Habéis ido de caza, antes?.. ${ }^{16}$

La rebelión provocó un enfrentamiento armado entre dos bloques. De una parte, el levantamiento militar de las fuerzas reaccionarias comandadas por el general Franco, apoyadas desde el primer momento por la Alemania nazi y la Italia fascista. De otra parte, el frente de las fuerzas republicanas, que actuaba en legítima defensa del orden democrático, entre las que se encontraban también los gobiernos nacionalistas catalán y vasco. ${ }^{17}$ Conviene señalar, de todos modos, que en Galicia no llegó a haber guerra, porque los sublevados se hicieron con el control del país, ya en los primeros momentos, desde entidades militares y civiles:

(47'05”) Los principales componentes de los grupos de represión eran tres: los militares, sujetos a la obediencia obligada a sus mandos, siendo ya fusilados los disidentes a la rebelión en los primeros momentos. A su vez, los falangistas y paramilitares, convertidos en auténticas máquinas de matar. En su ideología incluían las máximas de su líder, José Antonio Primo de Rivera. Una de las principales era: 'Hay veces en la vida en que se acaban los razonamientos y sólo queda la dialéctica de los puños y las pistolas'. Por último, las fuerzas policiales, principalmente los guardias civiles que, tras las primeras dudas abrazaban rápidamente la causa rebelde. Su implantación en el rural les hizo especialmente temibles. ${ }^{18}$

Esto provocó una feroz represión, con carácter sistemático y una brutalidad inhumana contra los afiliados, militantes y familiares de todas las fuerzas integrantes del Frente Popular. ${ }^{19}$ Esta situación vino a alterar las dinámicas de convivencia, especialmente

\footnotetext{
${ }^{16}$ Home sen nome (Edicións Xerais, 2006) es un relato de ficción intenso y emotivo centrado en los acontecimientos de la represión en Galicia durante los días del golpe de estado y los años de la posguerra.

${ }^{17}$ La organización estatal en 17 Comunidades Autónomas por la que se vertebra España en la actualidad como un estado plurinacional tiene su origen en el año 1931, con la Segunda República. Es en ese año cuando arranca el proceso que llevaría a la aprobación por las Cortes republicanas españolas del primer proyecto de Estatuto de Autonomía para Cataluña en 1932, y los del País Vasco en 1935 y Galicia en 1936. El de Galicia, aprobado en junio de ese año, no llegó a entrar en vigor debido al inmediato golpe de estado. Véase: Xusto G. Beramendi (2003).

${ }^{18}$ Abogado y político español, hijo del dictador Miguel Primo de Rivera (quien gobernó España después de un golpe de estado 1923-1930) y fundador del partito Falange Española. Fue acusado de conspiración y rebelión militar contra el Gobierno de la Segunda República, por lo que fue ejecutado el 20 de noviembre de 1936, convirtiéndose en un mártir al servicio de la causa franquista.

${ }^{19}$ La coalición electoral creada en enero de 1936 por los principales partidos de izquierda para concurrir a las
} 
en el mundo rural, donde la cultura comunal había alcanzado una proyección singular a través del sindicalismo agrario de diferente signo, bien fuese católico, socialista o galleguista. ${ }^{20}$ Este movimiento, que crece con vigor en Galicia durante la etapa republicana, acaba siendo segado de raíz, y sus restos reconvertidos en la red franquista de las Hermandades Sindicales de Labradores y Ganaderos a principios de los años 40, bajo la denominada Organización Sindical Española.

De este modo, la organización del movimiento agrarista fue sustituida por un clima de división y desconfianza, como efecto de dos formas combinadas de violencia: la represión física exterior, que resultó atroz, desproporcionada y liquidacionista. ${ }^{21}$ Bajo la consigna de "matarlos a todos", como señala Claudio Fernández Fer, se perpetraron ejecuciones a personas, en muchos casos, por el cargo, por el estatus. A ésta se unía la represión simbólica interior, con una fuerte carga psicológica: (49'40”) “El silencio se implantó en todo el país. Cada muerto arrastró con él a muchos más muertos en vida que, como una siniestra Santa Compaña, iba recorriendo la tierra atormentada". ${ }^{22}$ Sobre este aspecto, el actor Vicente Montoto pone voz a un fragmento de Escritores gallegos ante la guerra civil, del profesor Xesús Alonso Montero.

(14'16”) Llegó Atila, como decía Castelao. La barbarie sembraba ríos de cunetas de cadáveres. Cadáveres de profesores, de sindicalistas de militantes agrarios, de obreros conscientes de sus derechos, de escritores... y de tantos que de un modo u otro aspiraban a vivir en un

\footnotetext{
elecciones en el mes de febrero, denominada Frente Popular, consiguió ganar y gobernar hasta el golpe de Estado. En Cataluña se presentó una coalición equivalente, el Front d'Esquerres, nucleada en torno a Esquerra Republicana de Catalunya. En Valencia lo hizo también como Front d'Esquerres.

20 Se conoce como movimiento 'agrario' o 'agrarista' a la organización de los labradores gallegos en sociedades o en sindicatos de distinto signo con el objetivo central de la abolición de los fueros y el acceso a la propiedad de las tierras. Fue el primer movimiento de masas de la edad contemporánea, y tuvo cierta intensidad entre finales del siglo XIX y principios del XX, hasta la Guerra Civil, llegando a contar con más de mil organizaciones locales. Su objetivo consistía fundamentalmente en la lucha contra el sistema foral y contra el caciquismo, además de promover la innovación técnica y la modernización productiva del sector agrario gallego.

${ }^{21}$ El documental $O$ segredo da Frouxeira (Xosé Abad, 2010) se adentra en la historia de cuatro familias relacionadas por un suceso dramático, silenciado durante décadas, presentando un nuevo punto de vista sobre la Guerra Civil y sus consecuencias en la actualidad.

${ }^{22}$ En la tradición popular de Galicia, la Santa Compaña es una especie de reunión de almas del Purgatorio que desfilan en procesión por las noches, para un fin determinado. Véase: Carmelo Lisón Tolosana. La Santa Compaña. Madrid, Akal, 2004.
} 
mundo sin privilegios. En el que la justicia, que era una canción en el corazón de todos ellos, fuese cuanto antes una realidad. Camaradas míos fueron abatidos en Betanzos; en el Ribeiro, tierra de mis padres, en Santiago, en Ferrol y en tantos otros sitios del país. El mapa de Galicia sangraba. ${ }^{23}$

Explica Ángel Rodríguez Gallardo que, para acusar a las personas en los pueblos y aldeas, el régimen recurre a una plantilla fija, donde había gente que formaba parte del aparato represor, y otra que decide ofrecerse: "Esto debió afectar mucho al carácter de la gente, pues el terror acabó regulando no sólo la vida privada sino también la vida social" a causa de las delaciones y el colaboracionismo. Como también se pregunta José Luis Bóveda, hijo del político asesinado y símbolo del martirio galleguista, (53’05’) “una persona con miedo un día tras otro; una persona que tiene que ocultar cosas para evitar mayores persecuciones, ¿cómo no va a alterar su forma de ser?”. ${ }^{24}$ Conviene añadir que una parte importante del clero se alineó desde el primer momento con el bando de los sublevados: (1:13'40”): “El propio nombre de “Cruzada” con el que la Iglesia bautizó la sublevación militar fue utilizado por primera vez por el Arzobispo de Santiago".

En este ambiente de terror vecinal, la información de las delaciones pasa a ser una valiosa mercancía. Vale para ilustrar este hecho la carta que el entonces joven Camilo José Cela (más tarde popular escritor, ganador del Premio Nobel de Literatura en 1989) dirige al Comisario General de Investigación y Vigilancia. Manuel Abad sitúa al actor Francisco Durán (Morris) en los pasillos de una gran superficie comercial:

(50'10") Excelentísimo señor Comisario General de Investigación y Vigilancia: el que suscribe, Camilo José Cela y Trulock, de 21 años de edad, natural de Padrón (La Coruña), a Vuestra Excelencia, respetuosamente expone: que queriendo prestar un servicio a la Patria, solicita el ingreso en el Cuerpo de Investigación y Vigilancia. Cree prestar datos sobre personas y conductas que pudieran ser de utilidad. Que el Glorioso Alzamiento

\footnotetext{
${ }^{23}$ Xesús Alonso Montero. Os escritores galegos ante a Guerra Civil española1936-1939: textos e actitudes. Vigo, Galaxia, 2006.

${ }^{24}$ Alexandre Bóveda, que aparece citado en otras partes de este texto, fue uno de los intelectuales más relevantes de la época en Galicia. Maestro de profesión y político nacionalista, fue uno de los fundadores del Partido Galeguista, del que era diputado electo en febrero de 1936 integrado en el Frente Popular. Fue fusilado por los rebeldes el 17 de agosto de ese año. El documental Alexandre Bóveda, unha crónica da Galiza Mártir (Xan Leira, 2004) profundiza en su figura.
} 
Nacional se produjo estando el solicitante en Madrid, por lo que cree conocer la actividad de determinados individuos. Bien entendido que, si a juicio de Vuestra Excelencia soy más necesario en cualquier otro lugar, acato la decisión con total entusiasmo y disciplina. Dios guarde a Vuestra Excelencia muchos años. Madrid, 30 de marzo de 1938. Segundo Año Triunfal.

La delación fue una de las variadas formas de represión que, en Galicia, el nacionalismo demócrata y republicano padeció con toda intensidad. Como señala el historiador Emilio Gradío, desde el primer momento, el grado de represión estuvo planificado.

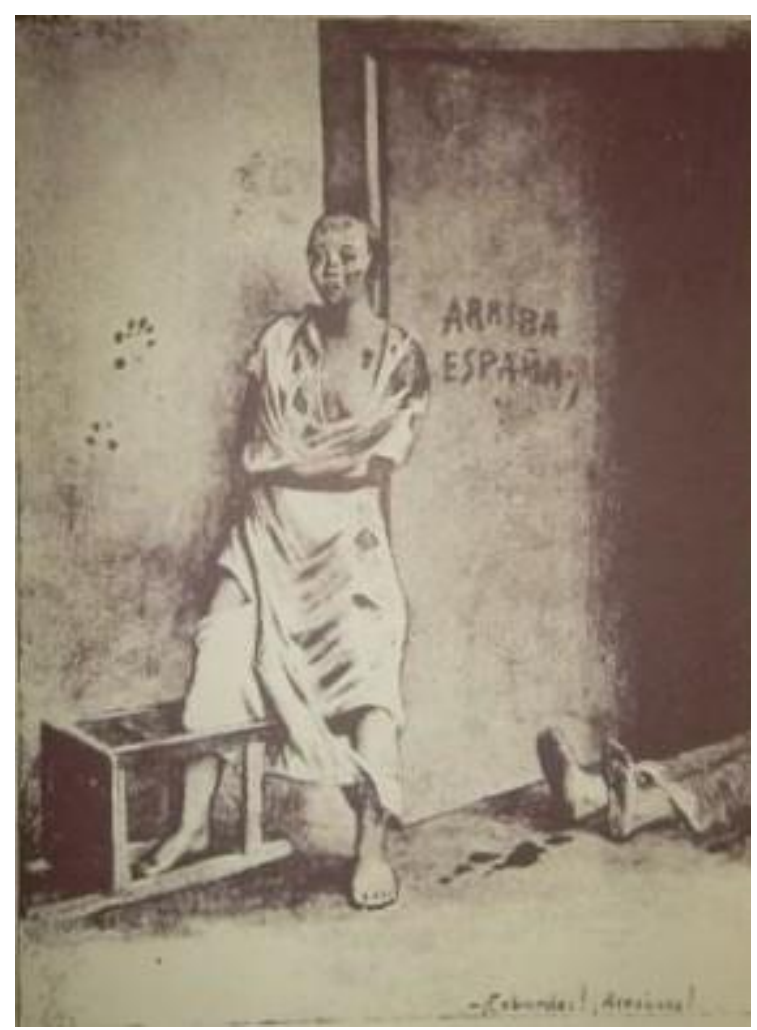

Ilustración n 3. “Cobardes, asesinos!”. Estampa del álbum Galiza Mártir (Castelao, 1937). Grito desgarrador femenino en la denuncia internacional de la represión franquista en Galicia. (Cortesía herederos Alfonso Daniel Rodríguez (astelao). 


\section{Cultura, idioma, ciudadanía}

El triunfo de las candidaturas republicanas en las ciudades precipitó la proclamación de la República el 14 de Abril de 1931 lo que, en opinion de Emilio Grandío (2003), provocó la propagación de una serie de expectativas y proyectos en ciertos sectores del Estado. Profesiones liberales, nueva burguesía comercial, movimiento obrero, sectores nacionalistas, nuevas elites políticas... tenían, en su conjunto, un proyecto de República. Aunque no necesariamente coincidente, todos compartían la urgencia contenida durante años para llevar a la práctica una necesaria regeneración de la sociedad. "Fue un día profundamente alegre - muchos, que ya éramos viejos, no recordamos otro más alegre - un día maravilloso en que la naturaleza y la historia parecían fundirse para vibrar juntas en el alma de los poetas y en los labios de los niños", escribió Antonio Machado. ${ }^{25}$

$\mathrm{Y}$ el nuevo gobierno tuvo que responder desde un principio al ansia general de progreso. De ese modo, durante el llamado Bienio Reformista (1931-1933), se desarrolló una extensa declaración de derechos y libertades. Entre sus principales medidas, se instituye el sufragio universal masculino y femenino, y como señala Gabriel Jackson (1985), tras un largo y complejo debate en las Cortes, las mujeres obtuvieron por primera vez en la historia, el derecho de voto. Siguieron otros derechos civiles como el divorcio, la equiparación de hijos legítimos e ilegítimos. O el derecho a la educación, empezando por la creación, en 1931, del Patronato de Misiones Pedagógicas (OTERO URTAZA, 1982). Era una vieja aspiración de la Institución Libre de Enseñanza, que proporcionó significativas experiencias de educación popular a los pequeños núcleos rurales a través del reparto de bibliotecas (MALHEIRO GUTIÉRREZ, 2017), la organización de conferencias, audiciones de música, proyecciones cinematográficas, exposiciones itinerantes con reproducciones de obras del Museo del Prado, representaciones teatrales y de guiñol... Para el profesor Manuel Tuñón de Lara, también exiliado a París en 1946, fueron precisamente las Misiones Pedagógicas la muestra más clara de ese tiempo de la gran ilusión, que representaron los primeros meses republicanos. Entre los avances en el terreno educativo figura, además, que la enseñanza

\footnotetext{
25 “El 14 de abril de 1931 en Segovia”. La Voz de España, abril de 1937.
} 
de la Religión católica dejó de ser asignatura obligatoria, lo que, por otro lado, agudizó el enfrentamento con la Iglesia a través de lo que se conoció como la "guerra escolar".

En relación a los Poderes del Estado, el legislativo quedó en manos de unas Cortes unicamerales, el ejecutivo se delimitaba con un Presidente de la República con escasos poderes y un Jefe de Gobierno, nombrado por el Presidente pero que debía contar con la aprobación de las Cortes; y el judicial en manos de los tribunales de justicia. Por primera vez se establecía el derecho de las distintas nacionalidades a dotarse de Estatutos de Autonomía. Se restauró, de ese modo, la Generalitat histórica en Cataluña y se concedió plena igualdad lingüística al idioma catalán. Más tarde sería el País Vasco y por último le Ilegaría también la oportunidad a Galicia con su propio Estatuto, aprobado en junio de 1936 (BERAMENDI, 2003).

Sobre la cuestión religiosa se estableció un estado laico, con la separación efectiva de la Iglesia y el Estado. Todas las órdenes religiosas debían registrar sus propiedades en el Ministerio de Justicia y presentar anualmente su declaración de ingresos. Se les prohibía dedicarse a actividades industriales, comerciales o de enseñanza; se les garantizaba, en cambio, la libertad de culto en privado, reservándose el Gobierno la autorización de las manifestaciones religiosas públicas. Ante estas medidas nunca antes promovidas, señala Jackson, el Vaticano calificó a la República de régimen “provisional”...

De este modo, el horizonte de progreso y modernidad que había ido germinando en el arranque del siglo XX y que empezó a florecer con la República a partir de 1931 fue extirpado de raíz. El actor Carlos Blanco evoca la represión contra el mundo del arte y la cultura a través del fragmento de un texto de Manuel Rivas (2006, 714), y lo hace desde un espacio tan simbólico como la biblioteca de la Facultad de Historia de la Universidad de Santiago:

(1:20'20") Había un libro en el escudo de la ciudad. El escudo de la ciudad es un faro. Pues bien, encima del faro había un libro. Ese libro lo quitaron y ya no volvió, no volvió. Ardieron montañas de libros, bibliotecas enteras, de las mejores. Las de los ateneos, "Germinal", la de Casares Quiroga. Oiríais hablar del señor Casares. También a él lo borraron. Incluso intentaron arrancar la hoja del Registro Civil de nacimientos. Le pasó a muchas personas lo del libro del escudo: que las borraron. 
Fue así como los valores democráticos que intentó implantar a partir del 14 de abril de 1931 fueron abruptamente interrumpidos por el golpe, y se instauró a partir de ese momento una dictadura militar amparada en los valores tradicionales mezcla de fascismo y nacional-catolicismo, en el clientelismo y la corrupción. Entre mediados de julio y mediados de septiembre se realizó una criba de todo elemento político republicano, estrictamente dentro de un contexto de trinchera, es decir, sin garantías ni derechos jurídicos de ningún tipo (GRANDíO, 2003). De tal modo que los avances iniciados por el primer gobierno reformista republicano de Manuel Azaña fueron tapados por la mordaza social de los vencedores, y la más dura represión, física y simbólica, contra los que acabaron perdiendo la guerra. Se limitaron los derechos fundamentales, se paralizaron los progresos en las ciencias y en las artes, así como las reformas emprendidas en el campo educativo o económico. Y se truncaron las perspectivas de poder consolidar una República federal que diera voz a las naciones que en ella habitaban. En el caso de Galicia, y en concreto sobre la represión de una manifestación tan genuina como el idioma, Henrique Monteagudo señala:

Durante la Guerra Civil: clausura, incautación y saqueo de la imprenta/editora Nós (el principal vehículo de publicación en la lengua del país en las décadas anteriores) después del asasinato ejemplarizante de su propietario, Ánxel Casal; desaparición del semanario A Nosa Terra y de la revista Nós; clausura e incautación del Seminario de Estudos Galegos y paralización de la publicación de sus Arquivos; aniquilación del Partido Galeguista y persecución de sus principales dirigentes mediante su eliminación, encarcelamiento o condena al exilio, las deposicións y las intimidaciones. Como consecuencia, en la década de los 40 el silenciamiento público del gallego fue casi total. (2008, p. 100)

La represión lingüística fue una de las numerosas manifestaciones de la represalia social, mediante la que también fueron asesinados o expulsados al exilio los miembros de dos generaciones de políticos demócratas, muchos de ellos de la órbita nacionalista; también intelectuales, profesorado de todos los niveles de la enseñanza; científicos, artistas, profesionales de diversas ramas, como ya hemos señalado, cuya ausencia vino a devaluar y debilitar la sociedad gallega en su conjunto. Fue así como pudo medrar, con energía renovada, el caciquismo, ahora reforzado por el colaboracionismo y la delación. 
Porque los rebeldes, persiguieron de manera deliberada la humillación de los vencidos a través del desprecio y el estigma, condenados en muchos casos al hambre, debido a la pobreza por falta de oportunidades: “Así, tras siempre en la Historia, siempre con mayúsculas de este país, los hijos de los leales, buenos y generosos, fueron y siguen siendo, toda su vida, los hijos de los rebeldes, los rojos o comunistas". ${ }^{26}$

\section{Los maestros republicanos, uno de los 'males' a erradicar}

Como venimos señalando, el proceso de represión se desarrolló en un clima de terror a fin de asegurar su eficacia punitiva y también preventiva. $Y$ se aplicó especialmente a los cuerpos docentes en todo el Estado, y así también en Galicia. En Flores tristes se hace referencia a la represión perpetrada contra este colectivo partiendo de una cita de Pablo Neruda: "Los maestros de Galicia han sido casi enteramente exterminados; la caza del maestro de primera enseñanza era un deporte diario de los falangistas". ${ }^{27}$ Y esto fue así debido a que los gobiernos republicanos de signo progresista, y especialmente en el primer bienio (1931-1933) habían convertido a los maestros en protagonistas simbólicos de la regeneración social que se intentaba emprender.

Por esto, la represión fue especialmente contundente, y sobre todo eficaz, entre el cuerpo docente significado con un modelo escolar laico, democrático y republicano de izquierdas. ${ }^{28}$ Pues se sabía que el profesorado era mucho más peligroso que un ejército regular: resultaba más fácil vencer a un ejército armado que a las ideas 'subversivas' de maestros que, además, actuaban en los pueblos, como misioneros laicos comprometidos con la libertad, la justicia social y el progreso. El terror ayudaba a prevenir, incidiendo no sólo en los 'culpables', sino también en los neutrales, con el objeto de conformar un

\footnotetext{
${ }^{26}$ Coralia e Maruxa. As irmás Fandiño (Xosé H. Rivadulla “Corcón”, 2007) describe el resultado de la violencia sistemática, física y psicológica, contra las hermanas Coralia y Maruxa, pertenecientes a una familia humilde se trabajadores vinculada a la CNT en el momento de la guerra. Violencia que se prolongó muchos años más durante la dictadura franquista en la persona de estas dos mujeres, obligadas por este motivo a vivir en la indigencia, parcialmente auxiliadas por la solidaridad de sus vecinos.

${ }_{27}$ Pablo Neruda. "A mis amigos de América". Nuestra España, 9 de marzo de 1937. Citado por Xesús Alonso Montero (2006, p. 183).

${ }^{28}$ Para profundizar en la represión sobre el magisterio puede consultarse: Francisco Morente Valero (2001).
} 
profesado dócil, cuando no simpatizante con los valores del nuevo Estado, cuyo aparato ideológico trataba de imponer, a partir del "Cara al sol”, ${ }^{29}$ una rancia formación patriótica y militarista, desde una interpretación fundamentalista de la religión y de la moral católicas.

De este modo, la violencia de un régimen ilegal, surgido de las armas, se proyectó contra aquellas personas, instituciones e ideas que representaban en sí mismas el 'mal' a erradicar: la escuela única, pública, laica y reformista fue objeto de un premeditado desmantelamiento, iniciado a partir del 1936 en la zona 'nacional', y que significó la derogación de la coeducación, la imposición obligatoria de la enseñanza de la religión católica, el derecho de inspección de la Iglesia sobre todos los niveles de enseñanza, la supresión de los Consejos escolares, el cierre de los institutos de bachillerato creados durante la Segunda República... Flores tristes recoge los casos de Arximiro Rico y Bernardo Mato, de entre el centenar de maestros y maestras asesinados en Galicia. Bernardo Mato fue golpeado y torturado hasta la muerte por ser simplemente un buen maestro.

Sentado a un pupitre de su escuela en Teo (A Coruña), el exalumno Severino Iglesias explica que lo mataron "simplemente por política. Fue una salvajada matar a ese hombre" (55'25”). Sobre Arximiro Rico, Manuel Sarille recuerda emocionado: (56'23") “es uno de los maestros fuera de serie. Educaba a los campesinos para cultivar la tierra, les enseñaba... un falangista, Bartolomé Fernández Valdeiglesia, analfabeto, sube a caballo de él, le quita los ojos, le corta los testículos, se los mete en la boca y le corta la lengua... No se puede explicar tanta barbarie". ${ }^{30}$ De este modo, la represión se extendió a las personas que encarnaban un ideario "institucionista, ateneísta, renovador o izquierdista" (ALONSO MONTERO, 2006, p. 183) cuya influencia debía ser aniquilada bien por eliminación física en los momentos más violentos, o bien mediante el aislamiento, la depuración o el exilio. En estas circunstancias de castigo, de muerte o de terror, para casi todos aquellos que mantenían el corazón republicano empezó una larga noche de exilio, interior en la mayor parte de los casos, y exterior en otros.

\footnotetext{
29 himno de la Falange Española de las JONS. Tras el final de la Guerra Civil, pasó a ser uno de los himnos oficiales franquistas, con obligación de ser entonado en todas las escuelas al inicio de la jornada escolar y al finalizar los actos oficiales.

${ }^{30}$ Sobre la figura de este maestro puede consultarse el trabajo de Narciso de Gabriel (2000).
} 


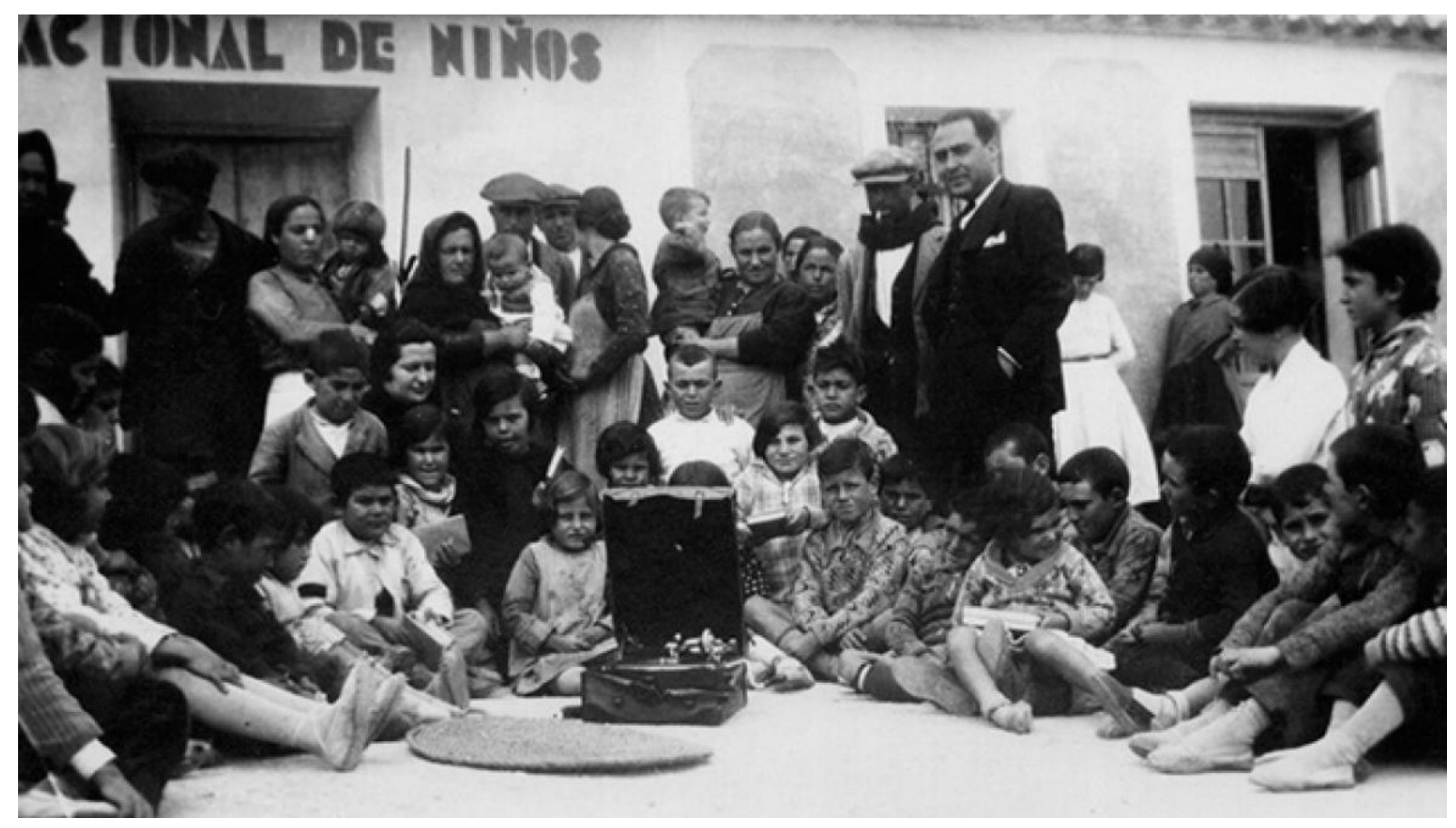

Ilustración n 4. Las Misiones Pedagógicas representan la preocupación de la República por la democratización de la cultura.

\section{Las diversas formas de exilio}

Sólo tuvieron oportunidad de salvarse quien en ese momento se encontraba fuera de Galicia o aquellos que consiguieron huir en los primeros días, bien buscando salida por vía marítima a diferentes lugares, o a través de la frontera portuguesa. ${ }^{31} \mathrm{El}$ puente internacional de Tui (Pontevedra) encarna las dificultades afrontadas por muchos ciudadanos republicanos huidos de la barbarie. La actriz Uxía Blanco pone voz a la carta (fragmento) que un grupo de españoles refugiados en Portugal dirige en 1937 al dictador Salazar, cuyo régimen mantuvo una postura abiertamente colaboracionista con los golpistas:

\footnotetext{
${ }^{31}$ El documental ¿Bandoleiros ou guerrilleiros? (José A. Sanmartín, 2006) recoge las vivencias de varios huídos durante la guerra civil, entre las que destaca el testimonio de una guerrillera que, siendo una niña, y junto a sus cinco hermanos, huyeron al monte formando su propia cuadrilla tras el asesinato de sus padres a manos de los falangistas. Afranio (Víctor Collote, 2008) narra las penurias del diputado agrarista Antón Alonso Ríos durante los tres años, los de la guerra civil, que duró su periplo como huido por tierras del sur de Galicia y norte de Portugal bajo la falsa identidad de un mendigo portugués, Afranio de Amaral. Otro trabajo Camilo: o último guerrilleiro de Galicia (Alba Sánchez, 2016) recupera la memoria de la guerrilla antifranquista a través del testimonio de Camilo de Dios, fallecido recientemente.
} 
(36'oo") Excelentísimo señor: Por muy respetuosos que queramos ser con su Excelencia no podemos silenciar estos hechos. Porque cuando sabemos que se nos persigue en Portugal para llevarnos a la muerte; cuando sabemos que horas después de ser detenidos seremos muertos unos metros más allá de la frontera portuguesa; cuando se tiene estas tremendas seguridades de la muerte, no se puede contener la protesta... 32

En el puerto pesquero de A Coruña la actriz Mela Casal evoca la huida desesperada de muchos ciudadanos como único recurso para salvar la vida. Indica el historiador Dionisio Pereira que el mar fue una fosa común en las Rías Baixas. (31'30") Sindicalistas de varias localidades sufrieron torturas en tierra, siendo posteriormente trasladados en embarcaciones cedidas por las patronales respectivas, para ser fondeados en medio de las rías. Jamás volvieron a aparecer. De tal forma que sus viudas nunca pudieron cobrar la pensión correspondiente. Se han documentado en torno a medio centenar de fugas, la mayoría de ellas con éxito. En los primeros tiempos en dirección a Asturias, Cantabria, el País Vasco; posteriormente a Francia o incluso al norte de África (PEREIRA, 2011).

Entre los numerosos intentos de huida por barco, sobrecoge el caso de un grupo que acabó en suicidio colectivo para evitar caer presos de los rebeldes al ser descubiertos antes de zarpar. La madrugada del 23 de abril de 1937 ocho hombres y una mujer, entre los 24 y los 44 años, murieron tras el asalto fascista al barco Eva, en el que pretendían huir desde el embarcadero del puerto de Vigo. Formaban el grupo cuatro jóvenes comunistas Ángel Nogueira Nogueira y Carmen Miguel Agra, recién casados; además de Luís Álvarez González, trabajador de astillero y Camilo Campos Méndez, de oficio barbero-; tres socialistas -el marinero Manuel Martínez Moroño y los hermanos Fernando y José Rodríguez Lorenzo, ambos albañiles- y dos maestros galleguistas, José Losada Castelao y Manuel Rodríguez Castelao, primos de Castelao, a quien ya hemos mencionado. Su propósito era alcanzar alguno de los puertos republicanos del Cantábrico o de Francia, para posteriormente trasladarse a territorio republicano, como ya lo habían logrado expediciones anteriores. Concha Nogueira, hija del matrimonio implicado en este

\footnotetext{
${ }^{32}$ La producción de la RTP portuguesa A Guerra também foi nossa (Ana Luísa Rodrigues, 2017), rescata historias inéditas de ciudadanos portugueses, fundamentalmente trabajadores fronterizos que, pese a no haber participado directamente en la guerra, fueron fusilados o desaparecieron a manos de los rebeldes franquistas.
} 
desgraciado suceso, recuerda el momento de la despedida y defiende la decisión de sus padres: (32'50") “Sabes lo que significa no entregarse a las hordas fascistas? Pues eso. No entregarse. Fueron unos valientes, a mi juicio y a mi pensar. Ellos también temían la tortura ¿tú no sabes que torturaban mucho? El hermano de papá, que torturaban a la gente, qué criminales. Papá llevaba un anillo y hasta se lo robaron, los falangistas, criminales”.

Por casi todo el mundo se dispersó el exilio gallego. Una parte de lo más preclaro de la intelectualidad del país estaba fuera de su tierra. La cultura que se marchitaba en el interior de Galicia florecía de nuevo fuera de ella gracias al privilegio de esta aportación intelectual. Entre los centenares de exiliados, en el documental se cita al escritor y periodista Eduardo Blanco Amor, al artista y escritor de ascendencia gallega nacido en Buenos Aires Luis Seoane, al maestro y político Antón Alonso Ríos, al sacerdote y destacado agrarista Basilio Álvarez, al historiador y político Emilio González López, a la pintora Maruja Mallo, al poeta de ascendencia gallega nacido en La Habana Lorenzo Varela, al artista multifacético Eugenio Granell, al pintor Manuel Colmeiro, al poeta y dramaturgo Rafael Dieste, al político Ramón Suárez Picallo, al escritor y diplomático Salvador de Madariaga o a la actriz María Casares, hija de Santiago Casares Quiroga, ministro y jefe de gobierno con Azaña.

Otros, fueron fusilados tras un consejo de guerra o simplemente asesinados sin garantías legales, como fue el caso del escritor y político Víctor Casas, del escritor y artista Camilo Díaz Baliño, de Johan Carballeira, seudónimo del periodista y político José Gómez de la Cueva; del editor y político Ánxel Casal, en aquel momento alcalde de Santiago de Compostela, o de Alexandre Bóveda, ya mencionado. En relación con este asesinato, las ruinas de una fábrica sirven como escenario al actor Manuel Lourenzo para leer la última carta que Bóveda dirige a su mujer, el 17 de agosto de 1936, poco antes de ser ejecutado:

(58'33") Choliñas! mi Peque, Vidiña: Quise escribirte mucho. Pero ya sabes cuánto podría decirte. Perdóname todo, que los peques me recuerden siempre; que cumplas todos mis encargos. Yo, Almiña, estaré siempre en vosotros como te prometí. (...) Muero tranquilo; confío en que seré recibido donde todos queremos juntarnos y lo hago con alegría confiando en Dios este sacrificio. Quise hacer bien, trabajé por Pontevedra, por Galicia y por la República y el errado juicio de los hombres (que yo perdono 
y todos debéis perdonar) me condena (...) Faltan unos minutos y tengo valor, por vosotros, por la Terra, por todos. Me voy tranquilo. Adiós vidiña. Vive para los peques y los mayores, jabrázalos, confórtalos! Sé tú, mi Pequeniña admirable, la más valiente de todos. Allá sentiré alegría y satisfacción de Ti y de todos. Os recordaré siempre, velaré siempre por vosotros. Adiós. Contigo, con los peques, con los mayores todos, estaré siempre en el recuerdo, en la más grande, la más honda, la más infinita de los brazos, vuestro Xandro. P.S./recé contigo.

Pero no se debe olvidar que también se produjo un exilio interior, mucho más difícil de cuantificar y cualificar, como consecuencia de la auto-represión y de la auto-censura que muchos gallegos y gallegas demócratas tuvieron que afrontar durante la longa noite de pedra ${ }^{33}$ que duró la dictadura franquista.

\section{El confinamiento en cárceles y campos de concentración}

Las cárceles y los campos de concentración se convirtieron en recintos insuficientes, en muchos casos improvisados en castillos, monasterios o antiguos lazaretos, donde los reclusos eran obligados a permanecer hacinados. En Galicia, se habilitaron 11 campos de concentración por donde pasaron entre 1936 y 1940 no menos de 30.000 presos políticos y prisioneros de guerra republicanos (HERNÁNDEZ, 2019). La mayor parte ubicados en la costa, por las facilidades que daba una óptima conexión marítima para el desembarco de prisioneros. Allí padecieron las penurias que provocaban el hambre, los castigos físicos y psicológicos y las enfermedades producidas por el hacinamiento en condiciones inhumanas. El documental recoge varios testimonios. Entre ellos el referido al campo de concentración de Rianxo (A Coruña), ubicado en una antigua fábrica de salazón, donde fueron recluidos unos 2000 presos. El actor Candido Pazó recita un fragmento de un texto escrito por el preso José Enrique Llera:

\footnotetext{
33 Longa noite de pedra (Larga noche de piedra) es el título del poema que forma parte del libro homónimo del poeta y escritor gallego antifranquista Celso Emilio Ferreiro (1912-1979). Un ejemplo de la poesía social de posguerra, que refleja la miseria de las clases trabajadoras, la emigración, la opresión política, el ansia de libertad y el antibelicismo. Longa Noite de Pedra (Vigo: Edicións Xerais de Galicia, 1962) alude metafóricamente al tiempo que duró, y fue soportada por una parte de la población, la dictadura de Franco.
} 
(1:02’30") Teníamos que cantar el Cara al Sol todos los días, dos veces. Una por la mañana, al izar la bandera y otra por la tarde, al bajarla. Firmes, con el brazo levantado. Parecíamos auténticos hitlerianos. Muchas noches nos ordenaban levantarnos rápidamente y formar. Entonces apagaban las luces y entraban las checas de Falange, y nos enfocaban con una linterna en la cara, uno a uno. Cuando reconocían a alguien, le mandaban dar un paso al frente, y lo esposaban. Se sentía perfectamente el 'clic' de las esposas al cerrarse. Se llevaron así a muchos camaradas. Al poco rato sentíamos las descargas, cerca del campo.

En otra secuencia, desde el embarcadero que lleva al penal instalado en un lazareto de la Isla de San Simón, en la ría de Vigo ("el emblema principal de toda esta ignominia”), ${ }^{34}$ el actor Gonzalo Uriarte reproduce unos fragmentos de la última carta de Ramiro Paz Carbajal, destacado socialista, fundador de varios periódicos y tipógrafo de profesión:

(1:07'10") A mi querida esposa. Hoy es domingo. Son cerca de las 9 de la mañana y ya se ve enfrente gran cantidad de gente que viene de los pueblos con el propósito de ver y hablar con sus familiares que se encuentran en este lazareto. Aquí sigo bien, siguen llegando presos de las cárceles de Partido. Ayer llegó una expedición de Cambados y otra de Arbo. De Pontevedra habían llegado anteayer ochenta y uno. Tenía que decirte algunas cosas que ahora en el momento de escribirte se me olvidan. En la carta de mañana procuraré comunicártelas. $Y$ nada más por hoy. Como siempre, da besos míos a los niños, Y tú con un beso fuerte, recíbelo también de tu esposo, Ramiro. ${ }^{35}$

En este contexto, señala la voz de Rosa Díaz, el mundo giraba al revés. (59’48”) Los procesos que se establecían contra los constitucionalistas, eran por rebeldía. Y los sediciosos y golpistas pasaban a usurpar el nombre de Ejército Nacional. Así, se construía una gigantesca mentira que, inexplicablemente todavía sigue vigente en nuestros días. Este sinsentido continuado generó un escalofriante espanto de silencio que, como si fuese un castigo divino, anegó varias generaciones: la que vivió esta situación y la de sus

\footnotetext{
${ }^{34}$ Existe otro trabajo documental, Aillados (Antón Caeiro, 1995) que recoge la experiencia de algunos de los presos que sobrevivieron en el lazareto de la isla de San Simón, considerada uno de los muchos puntos negros de la represión franquista en Galicia.

35 Puede consultarse también el trabajo de Xesús Alonso Montero (2009).
} 
descendientes que, al estar bajo el yugo de los vencedores, tuvieron la boca sellada a cal y canto durante casi cincuenta años. Toda una eternidad para un silencio.

Es necesario dignificar a las víctimas, señala la historiadora Carmen Blanco, devolverles la dignidad; decir quiénes eran y lo que estaban haciendo, porque en la mayoría de los casos, eran personas que estaban trabajando por la libertad. Añade Claudio Rodríguez Fer que lo que falta no es dignidad en las víctimas, sino dignificación. Es decir, el reconocimiento social de su dignidad.

\section{La Galicia actual}

¿Cómo sería hoy Galicia si los Daniel Castelao, Alexandre Bóveda, Arximiro Rico, Luís Seoane, Camilo Díaz, Ánxel Casal, Víctor Fráiz y tantos otros, hubieran podido continuar, durante las décadas siguientes, la labor iniciada? Sin duda, tendríamos un país más sano, más libre, más tolerante, más democrático, más culto y mucho más desarrollado. Fueron demasiadas las esperanzas segadas por la dictadura. Sus responsables nunca pagaron por ello, y en muchos casos, sus descendientes siguen ocupando en la actualidad espacios de poder.

Señala Rosa Díaz que todavía hoy, investigadores e historiadores tienen problemas al citar el nombre de los asesinos por temor a enfrentarse a las denuncias de sus descendientes, que utilizan la legalidad democrática que tanto combatieron. Como el caso de Dionisio Pereira, denunciado por la familia de un alcalde falangista a quien mencionó como represor en una de sus investigaciones. El documental ofrece imágenes de la vista oral donde Pereira sostiene la presunta implicación de Manuel Gutiérrez, entre otros, como “participantes o instigadores" en los actos que acabaron en agosto de 1936 con la vida de seis personas en la comarca de Terra de Montes. ${ }^{36}$ El historiador fue juzgado en $2007 \mathrm{y}$ finalmente absuelto: (03’56”) “En este mundo al revés creció toda una generación con las cicatrices del silencio. Una generación perdida, silenciada".37

\footnotetext{
${ }^{36} \mathrm{https}: / /$ elpais.com/diario/2008/06/02/sociedad/1212357601_850215.html.

37 Eu tamén necesito amar (Antón Caeiro, 2016) habla de esa generación que no ha vivido exactamente una guerra civil, pero padece, sin embargo, sus efectos, en concreto la represión de la dictadura sobre la vida
} 
(1:21'00") El silencio sigue funcionando. Muchos de los hijos, nietos o parientes de los asesinados durante la época del terror, todavía tienen miedo de hablar. Muchos se negaron a salir en cámara porque, todavía hoy siguen teniendo miedo. A pesar de todo, en ningún rostro hay rencor. En ningún gesto, venganza. Después de más de setenta años de sufrimiento, de soportar que sus seres queridos estén bajo tierra amontonados en fosas; de padecer cárcel, mentiras, desprecio, silencio, miedo... nadie reclama venganza, nadie predica odio, nadie reclama más batallas.

Somos lo que fuimos, afirma Emilio Grandío: cuarenta años de dictadura han tenido que dejar, inevitablemente, alguna huella en nosotros, (1:27'23”) “el problema viene cuando, después de treinta años de democracia, se generan unos nuevos valores de convivencia, de tolerancia, de sociedad civil... si los niños que crecen en esos valores, evidentemente encuentran esto como un desajuste". Un desajuste que puede observarse entre los valores de la dictadura y los de la convivencia, de la tolerancia y de la democracia.

Remata Teo Manuel Abad colocando el foco en las generaciones más jóvenes. En un aula de educación Secundaria, un grupo de adolescentes responden vagamente sobre lo que hemos tratado en estas páginas. ${ }^{38}$ (1:27’00”) “El silencio sigue perpetuándose, sigue funcionando y siendo eterno. Los nietos, biznietos o tataranietos de los muertos ni se acuerdan ni llegan nunca a estudiar en la escuela una versión que no sea la consensuada durante la Transición, bajo el mandato en Galicia de un ministro de Francisco Franco [Manuel Fraga Iribarne], autor del golpe de estado. El golpe es incesante. Tres generaciones después, sigue ahí, incrustado definitivamente en el inconsciente colectivo de los gallegos". La consigna ahora, advierte, non es el silencio: es el olvido.

\footnotetext{
íntima de las personas.

${ }^{8}$ Sobre este problema, es interesante el trabajo que describe A pegada dos avós (La huella de los abuelos, Xosé Abad, 2012), sobre la memoria histórica contada a un grupo de estudiantes de bachillerato por sus abuelos, víctimas del golpe de estado ocurrido 75 años antes.
} 


\section{El drama de los desaparecidos y la preservación de la memoria a través de algunos ejemplos en el cine documental latinoamericano}

Hemos intentado busca conexiones entre la represión franquista y las diferentes formas de represión llevadas a cabo como terrorismo de estado en América latina. Como en el caso de Flores tristes, han motivado la realización de infinidad de trabajos que tienen como preocupación común la preservación de la memoria sobre los abusos de poder, la injusticia y la tortura, que atraviesa una buena parte de su historia, en manos de dictaduras militares no tan distintas entre sí. Presentamos, en el marco de esta revista, algunos de ellos por su interés como material de uso en las aulas de los distintos niveles de enseñanza secundaria y universitaria. 39

De este modo, la preocupación por el olvido centra también la obra del documentalista chileno Patricio Guzmán. ${ }^{40}$ En la trilogía La batalla de Chile (La insurrección de la burguesía, 1975; El golpe de estado, 1977; El poder popular, 1979) narra el último año de gobierno de Salvador Allende, cuyo rodaje se prolongó hasta el mismo día de su derrocamiento. Después de sufrir represión y amenazas de muerte, Guzmán consigue salir del país llevando consigo el material rodado, y salvando con él la memoria, que logra montar y estrenar más tarde, ya en el exilio. Patricio Guzmán volverá a su país, algo más de dos décadas después, para encontrarse de nuevo con algunos de los protagonistas de esta trilogía y rueda Chile, la memoria obstinada. (1997). ${ }^{41}$ Su objetivo no es otro que documentar el olvido programado, la prohibición de recordar; los recursos de la memoria oficial para enterrar los horrores de la memoria real... y comprobar el escaso conocimiento que las

\footnotetext{
39 Pueden consultarse, entre otros: Rangil (2007) y Ruffinelli (2012).

40 Patricio Guzmán es uno de los cineastas chilenos de mayor reconocimiento internacional. Después del golpe de estado permaneció en el Estadio Nacional de Santiago, incomunicado y amenazado de fusilamiento. Abandonó Chile en noviembre de 1973. Ha vivido en Cuba, España y Francia, donde reside. Seis de sus obras han sido estrenadas en Cannes, entre las que sobresalen La Batalla de Chile (1975-1979) (https://www.youtube.com/watch?v=13CHmRPscpA), El Caso Pinochet (2001), Salvador Allende (2004) y Nostalgia de la Luz (2010) (https://www.youtube.com/watch?v=RuoZVjl6xNo). Con esta última recibió el Gran Premio otorgado por la Academia del Cine Europea en 2010. Su última obra El Botón de Nácar obtuvo el Oso de Plata en Berlín en 2015. Fue invitado a formar parte de la Academia de Hollywood en 2013. Es presidente y fundador del Festival Documental de Santiago, FIDOCS. Retrospectivas recientes: British Film Institute, Harvard Film Archive. Se puede encontrar esta información en: https://www.patricioguzman.com/es/.
}

${ }^{41}$ Acceso a fragmento del documental: https://www.youtube.com/watch?v=fOVV5R7lsul. 
nuevas generaciones poseen de la dictadura pinochetista y su fragmentaria opinión sobre lo ocurrido en Chile tras el golpe de estado.

En En nombre de Dios (1987) ${ }^{42}$ nos muestra el impresionante movimiento de masas que se generó contra Augusto Pinochet en 1985 en los barrios populares, universidades, sindicatos de Santiago. Un movimiento de contestación popular que fue acompañado ejemplarmente por la Iglesia católica chilena a través de la "Vicaría de la Solidaridad", enfrentada a la dictadura militar, y soporte solidario de equipos de asistentes sociales y abogados para defender a los presos ante los tribunales y tratar de localizar los cuerpos de los “desaparecidos".

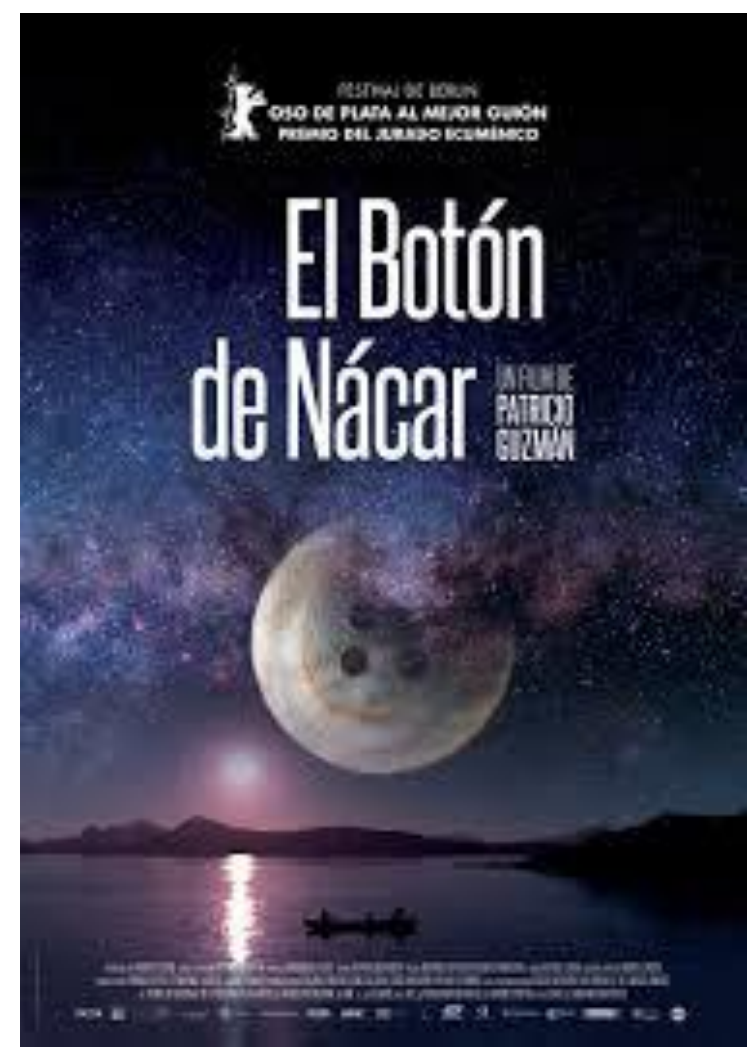

Ilustración $n^{\circ} 5$. El botón de nácar (2015), un trabajo reciente de Patricio Guzmán plantea el drama chileno de la violencia de estado.

\footnotetext{
${ }^{42}$ Acceso a fragmento del documental https://www.youtube.com/watch?v=ZGDzJ3T9P_o.
} 
Informes y Testimonios: la Tortura Política en Argentina (Diego Eijo, Eduardo Giorello, Ricardo A. Moretti, Alfredo Oroz, Carlos Vallina, Silvia Verga, 1973) ${ }^{43}$ denuncia los métodos de secuestro y tortura empleados en Argentina durante la dictadura de Juan Carlos Onganía (1966-1970). Fue rodada por un grupo de egresados en Cinematografía de la Universidad de La Plata (Buenos Aires), entre 1972 y mediados de 1973 combinando testimonios de madres de desaparecidos, de abogados y de psicólogos ("Partimos de la hipótesis de que el torturador es un tipo cualquiera. El torturador es un tipo que, si se lo ve fuera de la tortura o en cualquier otro lugar, no manifiesta ninguna característica extraña de personalidad. Creo que es un tipo común y silvestre (... ) no hay elementos vocacionales o predisposiciones naturales a ser torturador. Realmente se hace") con la reconstrucción de interrogatorios y sesiones de tortura de extrema crudeza.

El 17 de septiembre de 1977, Etelvino Vega y María Esther “Cuqui” Ravelo, una pareja de jóvenes invidentes, fueron secuestrados y desaparecidos en la ciudad de Rosario, junto a su hijo Iván, en un operativo de represión dirigido por un comando del II Cuerpo de Ejército a cargo de Leopoldo Galtieri. Tenían 33, 23 y 3 años respectivamente. Etelvino militaba en los Montoneros, una organización guerrillera marxista. El niño fue entregado días después a unos familiares. La casa familiar, ubicada en la calle Santiago 2815 de Rosario (Santa Fe), fue expropiada por el Ejército para establecer allí la sede del Centro de Suboficiales y Gendarmes retirados Guarnic. 1977, casa tomada (María Pilotti, 1999) recoge los hechos y el empeño de Iván por recuperar su vivienda, ilegalmente ocupada, con el apoyo de las Madres de Plaza de Mayo, que acabó convirtiendo en sede de la Asamblea Permanente por los Derechos Humanos "Casa de la Memoria".

Entre 1973 y 1985 se implantó en el Uruguay una dictadura después del golpe de estado dado por el presidente Juan María Bordaberry con el apoyo de las fuerzas armadas. Decile a Mario que no vuelva (Uruguay, 2007) ${ }^{44}$ compone una galería de testimonios de policías, políticos y un militar preso, que ilustran con humor negro, conciencia política y

\footnotetext{
${ }^{43}$ Acceso al documental: https://www.youtube.com/watch?v=YYaBloEL_os\&t=2154s.

${ }^{44}$ Acceso al tráiler: https://www.youtube.com/watch?v=gIPrUgNhyso
} 
mucho realismo una visión densa y precisa de este periodo. Mario Handler ${ }^{45}$ realiza este trabajo a su regreso a Uruguay, tras un largo exilio en Venezuela, en señal de gratitud hacia los compatriotas que durante ese tiempo soportaron la dictadura, y acaba comprobando cómo ésta sigue presente en la vida pública, en los medios y, sobre todo, en la memoria de la gente.

Ayotzinapa: El paso de la tortuga (Enrique García Meza, 2017) ${ }^{46}$ trata sobre el secuestro y desaparición forzada de 43 estudiantes normalistas de la Escuela Rural de Ayotzinapa en septiembre de 2014. Las escuelas normales rurales gozan de tradición y arraigo en la sociedad mexicana desde los inicios de la Revolución, y en algunos estados, destaca el alto nivel de conciencia política de sus estudiantes. Detrás de la masacre de Iguala, que tuvo una gran resonancia internacional, asoma el problema del crimen organizado resultante de las conexiones y complicidades entre las autoridades y el narcotráfico. El documento perfila con precisión algunos de los protagonistas de esta historia, y resulta muy elocuente el testimonio de la periodista Anabel Hernández: "Al menos dos de los cinco autobuses en los que viajaban los normalistas esa noche portaban, por confusión, un cargamento de heroína por valor de 2 millones de dólares. El capo dueño de esta mercancía ordena al Ejército, autoridad máxima y la única capaz de coordinar el operativo conjunto, que había que recuperar la droga a cualquier precio", que resultó ser la vida de 43 jóvenes inocentes. Además de la denuncia de los asesinatos, García Meza llama a la conciencia colectiva sobre la situación de violencia que se vive en México, con más de 60.000 desapariciones y la impunidad con la que actúan los cárteles.

500 años (Pamela Yates, 2017)47. El título del documental hace referencia a "larga

\footnotetext{
45 Mario Handler (Montevideo, 1935) es un reconocido cineasta y fotógrafo, considerado como pionero del cine militante uruguayo, con formación en Alemania (Institut für den Wissenschaftlichen Film) y Checoslovaquia. Vanguardista (1958). Otras películas son Liber Arce, liberarse (1969). El Problema de la Carne y Fray Bentos: una Epidemia de Sarampión (1973), Dos puertos y un cerro (1975), Tiempo colonial (1976). [https://www.retinalatina.org/person/mario-handler/]

${ }^{46}$ Acceso al documental: https://www.youtube.com/watch?v=z6UL74vh5UA\&t=3492s

47 Pamela Yates es una documentalista estadounidense y activista de derechos humanos. Es cofundadora y directora creativa de Skylight (https://skylight.is/), una empresa sin ánimo de lucro dedicada a la creación de largometrajes documentales y herramientas de medios digitales que fomentan la conciencia de los derechos humanos y la búsqueda de la justicia mediante la puesta en marcha de campañas de divulgación diseñadas para comprometer, educar y activar el cambio social. Ha dirigido películas sobre crímenes de guerra, racismo y genocidio en los Estados Unidos y América Latina: When the Mountains Tremble (1982), State of Fear. The
} 
noche de los pueblos", que es como denominan los mayas los cinco siglos de resistencia frente a los intereses políticos y económicos de las oligarquías opresoras, aunque este largometraje trata especialmente sobre los tres más tumultuosos de la historia reciente de Guatemala, entre 2013 y 2015. Es el periodo que va del juicio por genocidio al exdictador Efraín Ríos Montt, acusado por su participación en el asesinato de más de 1.700 indígenas de la etnia Ixil, a la dimisión y entrada en prisión del expresidente Otto Pérez Molina, acosado por diferentes casos de corrupción. Aquí concluye un periodo que empieza varias décadas más atrás, cuando el pueblo maya vivió un sangriento conflicto que abarca una guerra civil, un genocidio y más de 200.000 víctimas indígenas, según informes de la ONU. 500 años es, de algún modo, la victoria del activismo promovido por el movimiento popular guatemalteco, el resultado de la resistencia social de la población para defender sus territorios y con ellos su cultura y forma de vida.

Aunque la temática no tiene que ver estrictamente con la violencia ejercida por motivos políticos, el documental brasileiro que incluimos trata sobre la considerada, hasta ese momento, mayor violación de derechos humanos ocurrida en toda la historia de Brasil: la conocida como masacre de Carandiru. La Casa de Detenção de São Paulo, en el barrio del que toma el nombre, fue construida en 1920, y considerada en aquel momento como prisión modelo. Fue el mayor penal de América del sur, diseñado para albergar a más de 8.000 presos. O prisioneiro da grade de ferro (auto-retratos) ${ }^{48}$ fue escrito y producido en 2003 por Paulo Sacramento a partir del informe homónimo elaborado por el periodista Percival de Souza en 1983, y a raíz de la masacre de Carandiru ocurrida en 1992, tras una revuelta, que ocasionó el asesinato de 111 presos a causa de la nefasta actuación de la policía. Nueve años después, en el 2001, un grupo de presos consigue gravar escenas de la vida en el interior, previamente adiestrados para el manejo de cámaras. El documental expone la realidad interna del penal a partir de los registros realizados por los presos durante varios meses. Muestra las condiciones inhumanas que padecen los reclusos, revela la ineficacia del sistema penitenciario brasileño y el fracaso de su proceso de reinserción; e

\footnotetext{
Truth About Terrorism (2005), The Reckoning. The Battle for the International Criminal Court (2008), Dictador in the Dock (2013), Disruption (2014) Rebel citizen (2015) Mother tongue (2015).

${ }^{48}$ Acceso al documental: https://www.youtube.com/watch?v=dllv7Pg5Udo.
} 
invita a reflexionar sobre la vulneración de los derechos humanos en las cárceles. El penal fue demolido en 2002.

\section{Referencias}

ALONSO MONTERO, Xesús. Os escritores galegos ante a Guerra Civil española 1936-1939: textos e actitudes. Vigo: Editorial Galaxia, 2006.

ALONSO MONTERO, Xesús (ed. lit.). Cartas de republicanos galegos condenados a morte (1936-1948). Vigo: Edicións Xerais de Galicia, 2009.

AUMONT, Jacques et al. Estética del cine. Espacio fílmico, montaje, narración, lenguaje. Titivilus. Edición digital ePub r1.2, 1996.

BARSAM, Richard Meran. Non-Fiction Film: a Critical History. Bloomington, IN: Indiana University Press, 1973.

BERAMENDI, Xusto G. Nacionalismos, regionalismos y autonomía en la Segunda República. Pasado y memoria. Revista de Historia contemporánea, n. 2, p. 53-82 2003.

BERAMENDI, Xusto G. Historia mínima de Galicia. Madrid: Turnes Ediciones, 2016.

BREU, Ramón. El documental como estrategia educativa. De Flaherty a Michael Moore, diez propuestas de actividades. Barcelona: Graó, 2010.

BURKE, O. Visto y no visto. El uso de la imagen como documento histórico. Barcelona: Crítica, 2005.

CATALÀ, Josep María; CERDÁN, Josetxo. Después de lo real. Pensar las formas del documental, hoy. Archivos de la filmoteca. Revista de estudios históricos sobre la imagen, n. 57, p. 6-25, 2008.

DE GABRIEL, Narciso. Arximiro Rico. Vida e morte dun mestre republicano. Sarmiento.

Revista galego-portuguesa de historia da educación, n. 4, p. 9-38 2000. 
DE TORO, Suso. Home sen nome. Vigo: Edicións Xerais, 2006.

DEL REY REGUILLO, Antonia. La represión franquista en el ámbito profesional. Archivos de la filmoteca. Revista de estudios históricos sobre la imagen, n. 30, p. 55-90, 1998.

FERREIRO, Celso Emilio. Longa Noite de Pedra. Vigo: Edicións Xerais, 1962.

GRANDíO, Emilio. Estratexias de control dun conflicto civil: Galicia, 1936-1939. In: A Represión franquista en Galicia. Actas do Congreso da Memoria. Narón: Asociación Cultural Memoria Histórica Democrática, 2003, p. 64-80/66.

GUICHOT REINA, Virginia. Cine y memoria histórica: la interpretación del pasado reciente nacional en el cine de la transición española (1975-1986). Revista Iberoamericana de Patrimonio Histórico-Educativo 3 n. 1, p. 70-96 2017.

HERNÁNDEZ DE MIGUEL, Carlos. Los campos de concentración de Franco.

Sometimiento, torturas y muerte tras las alambradas. Barcelona: Ediciones B., 2019.

JACKSON, Gabriel. La República española y la Guerra civil, 1931-1939. Barcelona: Orbis, 1985.

LISÓN TOLOSANA Carmelo. La Santa Compaña. Madrid: Akal, 2004.

MALHEIRO GUTIÉRREZ, Xosé M. Las bibliotecas escolares en la primera década del franquismo. Entre el amanecer y la luz cegada. História da educação, 21 n. 53, p. 239-266, 2017.

MONTEAGUDO, Henrique. Ramón Piñeiro, a Editorial Galaxia e a Real Academia Galega (1950-1962). Estratexias de resistencia idiomática fronte ao franquismo. Grial: revista galega de cultura, n. 177, p. 98-111, 2008.

MORENTE VALERO, Francisco. La muerte de una ilusión el magisterio español en la Guerra Civil y el primer franquismo. Historia y comunicación social, n. 6, p. 187-201, 2001.

NERUDA, Pablo. A mis amigos de América. Nuestra España, 9 de marzo de 1937.

OTERO URTAZA, Eugenio. Antonio Ramos Varela. Noticia dun intelectual libertario esquecido. Boletín Galego de Literatura, n. 39-40, p. 297-310, 2008.

PEREIRA, Dionísio. Loita de clases e represión franquista no mar (1864-1939). Vigo: Edicións Xerais, 2011.

RANGIL, Viviana (Coord.). El cine argentino de hoy: entre el arte y la política. Buenos Aires: Biblos, 2007.

RIVAS, Manuel. Os libros arden mal. Vigo: Edicións Xerais, 2006. 
RUFFINELLI, Jorge. América latina en 130 documentales. Santiago de Chile, Uqbar editores, 2012.

OTERO URTAZA, Eugenio. Las Misiones Pedagógicas. Una experiencia de educación popular. Sada-A Coruña: Ediciós do Castro, 1982. 